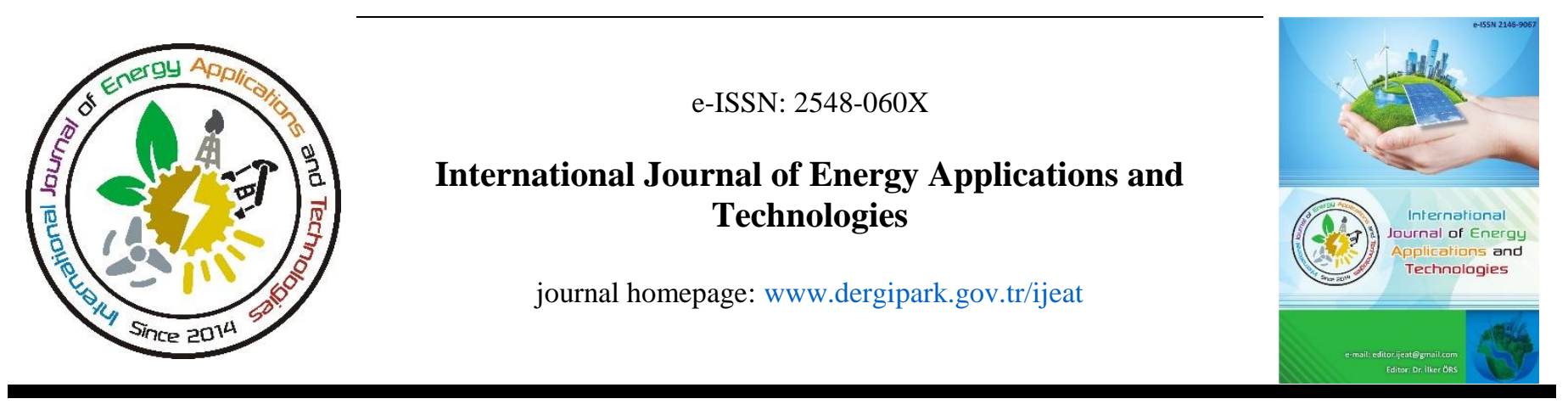

Original Research Article

\title{
Detecting chemicals with high yield in pyrolytic liquid of spirulina sp. microalgae via GC-MS
}

\author{
Gamze Özçakır ${ }^{1 *}$, Ali Karaduman ${ }^{2}$ \\ ${ }^{I}$ Chemical Engineering Department, Faculty of Engineering, Bilecik Seyh Edebali University, Bilecik, Turkey \\ ${ }^{2}$ Chemical Engineering Department, Faculty of Engineering, Ankara University, Ankara, Turkey
}

\author{
ARTICLE INFO \\ * Corresponding author \\ gamze.ozcakir@bilecik.edu.tr \\ Received July 20, 2020 \\ Accepted October 27, 2020 \\ Published by Editorial Board \\ Members of IJEAT \\ (C) This article is distributed by \\ Turk Journal Park System under \\ the CC 4.0 terms and conditions. \\ doi: 10.31593/ijeat.772113
}

\begin{abstract}
Pyrolysis of Spirulina sp. Microalgae was carried out in a semi-batch glass reactor system. Effect of temperature on the yields of pyrolytic products (gaseous, liquid and solid residue) and chemical composition of the liquid products were investigated. All experiments were performed in $25 \mathrm{~mL} / \mathrm{min}$ nitrogen atmosphere with $15 \mathrm{~g}$ feedstock which was dry and powder form of Spirulina. Temperature was varied from 470 to $620{ }^{\circ} \mathrm{C}$ with $50{ }^{\circ} \mathrm{C}$ break by utilizing PID controller which was setted $10{ }^{\circ} \mathrm{C} / \mathrm{min}$ heating rate. The aqueous phase and bio-oil (organic phase) of the liquid products were characterized by GC-MS. Maximum yields of bio-oil and aqueous phase were obtained approximately as $30 \mathrm{wt} . \%$ at $520^{\circ} \mathrm{C}$ and as $20 \mathrm{wt} . \%$ at $470{ }^{\circ} \mathrm{C}$. It was detected that bio-oil composed of aliphatic and cyclic hydrocarbons (such as toluene and heptadecane), oxygenated components (such as phenol, o-cresol and nonadecanol), nitrogenous components (such as hexadecaneamide and 3-Methyl-1H-indole). Unlike bio-oil, hydrocarbons like toluene, ethyl benzene, styrene and alkanes were not detected in aqueous phase.
\end{abstract}

\section{Introduction}

Due to run out of fossil fuels, researchers have studied on renewable and sustainable energy sources that are wind, solar, tide, waste and biomass. Plants, algae, animal wastes are in biomass class [1-3]. Biofuel (bioethanol, biodiesel, biogas) are obtained from biomass [4-6]. Besides that, biomass can be used for produce green chemicals, adsorbent and catalyst by pyrolysis [7-9].

Invaluable liquids which can be fuel or the source of green chemicals produce from biomass by using thermochemical or biochemical processes. Biochemical processes are required to hazardous chemicals like methanol and sodium hydroxide and energy [10]. In addition, they include many steps [11]. But, thermochemical process especially pyrolysis is a process which are preferred a lot. Because, it can be obtained solid, liquid and gaseous product simultaneously in one step at short time with pyrolysis [12,13]. Pyrolytic products yields depend on several factors. Biomass type, reaction conditions (temperature, heating rate, duration time), reactor configuration and catalyst using are these factors. The most important ones are temperature and heating rate $[14,15]$. Biomass feedstock amount don't affect pyrolytic product yields.

Microalgae as a biomass source of pyrolysis can be cultivated in wastewater and barren fields in a short span of time. Additionally microalgae are carbon-neutral, i.e., carbon dioxide was taken by them from the atmosphere during photosynthesis is equal to released carbon dioxide when they are used for whatever purpose [16,17].

Liquid product of microalgae pyrolysis includes two phases that are called aqueous phase and bio-oil. These two phases can be separated from each other easily [18]. There was too many researches about obtaining microalgal bio-oil. 
Chaiwong et al. (2013), fulfilled pyrolysis of Spirulina as a microalgae in fixed bed reactor at $450-600^{\circ} \mathrm{C}$. They obtained maximum bio-oil yield at $550{ }^{\circ} \mathrm{C}$ and determined the main components of bio-oil are heptadecane, toluene, ethylbenzene and indole as a result of GC-MS analysis [19]. Chen et al. (2017), carried out pyrolysis for three different types of microalgae in fixed bed reactor at $400-800{ }^{\circ} \mathrm{C}$. They obtained that peak area of aromatic hydrocarbons in bio-oil increased with temperature for all types of microalgae as a result of GC-MS analysis [20]. Andrade et al. (2018), worked between 450 and $750{ }^{\circ} \mathrm{C}$ for a microalgae. They determined that cyclic hydrocarbons and toluene increased with temperature [21].

Arthrospira platensis (Spirulina platensis) has been known as scientific name of Spirulina

microalgae. Spirulina which belongs to the blue green algae class has cultivated in a large

scale on the world [22]. For example, in China Spirulina production is approximately 10,000 Tons per year [23]. Spirulina has the highest product yield among microalgae species [24]. It has high carotenes and gamma-linolenic acid content, so the most popular application area of Spirulina has been food supplement sector [22]. Bio-oil production has been another application area of Spirulina. Bio-oil has thought alternative fuel to diesel. While low quality bio-oil can be obtained from lignocellulosic biomass sources, Spirulina supplies bio-oil whose features are stable, improved high heating value (HHV) and low oxygen content. These properties arise from lipid and protein content. Undesired linear hydrocarbons which decrease the bio-oil quality occur from lipid degradation in biomass. Spirulina has low lipid content. Besides that, its high protein content promotes aromatic hydrocarbon production which increases bio-oil quality as well [25]. On dry basis, Spirulina's weight comprises of approximately $60 \%$ protein and $10 \%$ lipid [26]. Compared to other biomass types (land and coastal types), $\mathrm{Li}$ et. al. decided that Spirulina has low activation energy for total conversion and therefore it should be prefer thermochemical conversion [24]. Apart from these important properties, Spirulina has high atomic nitrogen $(\mathrm{N})$ content, so it can be possible to see nitrogenous compounds in its bio-oil which results from thermal degradation of the biomass [22].Thermal degradation of Spirulina originates from three steps which are dehydration, de volatilization and carbonization. Firstly, up to $140{ }^{\circ} \mathrm{C}$ moisture of the microalgae evaporates. Secondly, up to $550{ }^{\circ} \mathrm{C}$ carbohydrates, lipids and proteins in the biomass degrades to main pyrolysis products and mass loss of biomass is high (65 $\%$ ). Above $550^{\circ} \mathrm{C}$, carbonization takes place and mass loss of the microalgae is low $(9 \%)$ [25]. After $600{ }^{\circ} \mathrm{C}$, it has been known that Spirulina amount almost don't change [22].

In this research, we aimed to observe temperature $(470,520$, $570,620^{\circ} \mathrm{C}$ ) effect on the product (bio-char, liquid, gaseous) yields and the liquid composition by carrying out pyrolysis of Spirulina sp. microalgae. Bio-oils were analyzed by GCMS comprehensively. In addition, unlike other researches in literature, we examined aqueous phase composition as well.

\section{Materials and Methods}

\subsection{Characterization of sample}

Spirulina in powder form was bought from a local herbalist. Particle size measurement of the Spirulina was made by using Malvern Mastersizer 2000 Particle Size Analyzer. According to the analysis results, average particle size of the sample was detected $37 \mu \mathrm{m}$ by volume. Elemental analysis of Spirulina was performed by utilizing Leco brand and CHN628 model with Sulfur add-on module equipment. Result of the analysis was shown in Table 1.

Table 1. Elemental composition of microalgae (wt. \%, ash free and dry basis)

\begin{tabular}{ccccc}
\hline $\mathbf{C}$ & $\mathbf{H}$ & $\mathbf{N}$ & $\mathbf{S}$ & $\mathbf{O}$ \\
\hline 46.69 & 6.22 & 10.76 & 1.55 & 34.78 \\
\hline *by difference & & &
\end{tabular}

\subsection{Pyrolysis of microalgae}

Thermal experiments were made as the following. It was used that tubular pyrex glass reactor has $4 \mathrm{~cm}$ diameter and $33 \mathrm{~cm}$ length. Reactor which had fulled of $15 \mathrm{~g}$ feedstock was settled vertically in handmade ceramic furnace. Furnace temperature and heating rate were controlled by Protherm brand PID controller. Inner temperature of the reactor was measured by Elimko brand $2000 \mathrm{M}$ model digital display device linkes NiCr-Ni thermocouple. The scheme of reactor in furnace was shown in Fig. 1. Firstly, PID controller temperature was adjusted to desired temperature (T1) with a heating rate. Secondly, temperature increasing in furnace was seemed on PID screen (T2) with taking signals from furnace to PID. At the same time, reactor temperature can be read on digital display (T3).

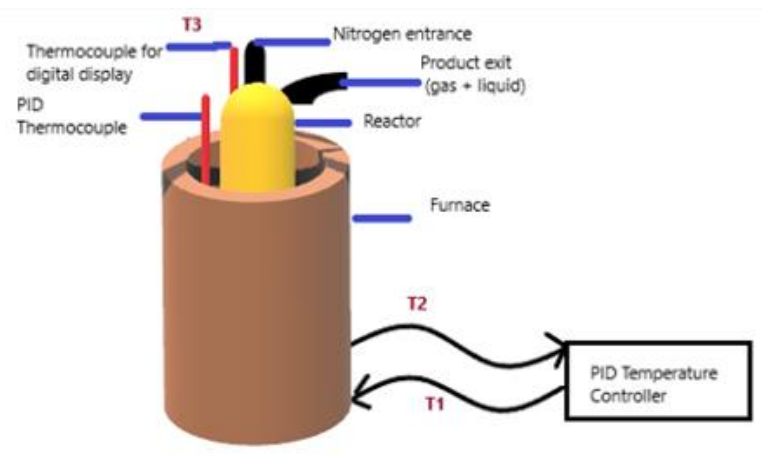

Fig. 1. Reactor in furnace

Reactor was used in experiments was operated at temperature range which is $470-620{ }^{\circ} \mathrm{C}$ during $60 \mathrm{~min}$. Its heating rate was chosen as $10{ }^{\circ} \mathrm{C} / \mathrm{min}$. Throughout the experiments nitrogen gas had $25 \mathrm{~mL} / \mathrm{min}$ flowrate was passed through 
glass setup which has a gap is open to the atmosphere. Products moved away the reactor in gas form gattered after they had passed a condenser. Non-collecting ones were released to atmosphere. Condensing liquid was mono ethyleneglycol and it held $0{ }^{\circ} \mathrm{C}$ by PolyScience brand circulator.

Product yields were calculated by using Equ. 1-4. The setup was shown in Fig. 2.

Bio-char yield $(\%)=($ rae, g-empty reactor, g $) /($ fie, $\mathrm{g})$

rae: reactor after experiment

fir: feedstock in the reactor
Liquid yield $(\%)=($ tlgee, $\mathrm{g}) /($ fir,, $\mathrm{g})$

tlgee: total liquid in glass equipments after experiment

Gaseous yield $(\%)=100-($ Bio-char yield + liquid yield $)$

Total conversion $(\%)=$ liquid yield + gaseous yield

Reactor configuration was selected to compare other researches about microalgae. For example, Chaiwong et al. (2013) worked with $6 \mathrm{~cm}$ inner diameter fixed bed reactor and under $30 \mathrm{~mL} / \mathrm{min} \mathrm{N}_{2}$ flowrate [27]. Thus, Velocity of the swept gas of our study $(2 \mathrm{~cm} / \mathrm{min})$ is same as this study $(1.1$ $\mathrm{cm} / \mathrm{min}$ ). Besides that, small reactor diameter is important for removing volatile matters in reactor quickly [28].

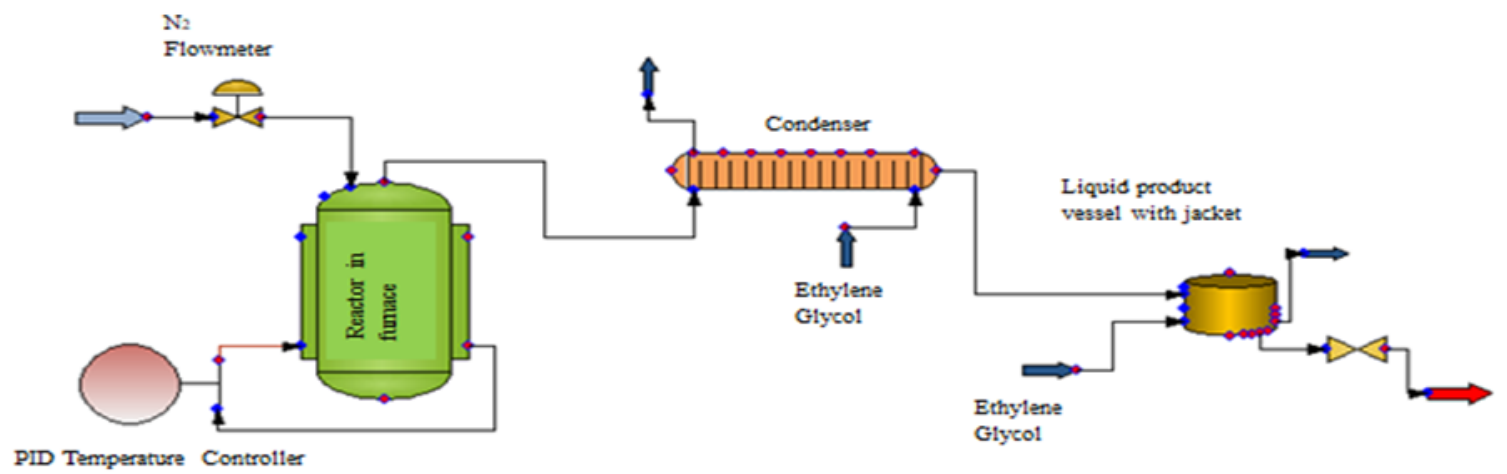

Fig. 2. Chemcad drawing of the experimental setup

\subsection{GC-MS analysis of pyrolytic liquid}

Compositions of bio-oil and aqueous phase were analyzed by utilized GC-MS whose brand and model were Thermo Finnigan and DSQ 250 respectively. Capillary column whose brand and model were Zebron and ZB-1MS respectively was found in the equipment. The column whose inner diameter was $0.25 \mathrm{~mm}$ had $60 \mathrm{~m}$ length. The column was able to operate between 30 and $370{ }^{\circ} \mathrm{C}$. Analysis conditions were as follows. Sample volume was chosen as $0.5 \mu \mathrm{L}$. Ion source temperature was adjusted to $220^{\circ} \mathrm{C}$. Column temperature was increased gradually. Firstly, the column was held $45^{\circ} \mathrm{C}$ for 4 min. After that, its temperature was risen to $280{ }^{\circ} \mathrm{C}$. Within that period, heating rate was determined as $3^{\circ} \mathrm{C} / \mathrm{min}$. Run of the total analysis was maintained at $102 \mathrm{~min}$.

\section{Results and Discussion}

\subsection{Yields of pyrolysis products}

Effect of temperature on the product yields and total conversion (gaseous + liquid product yield) was given in Fig. 3. Liquid product yield was obtained as nearly $45 \%$ at $470^{\circ} \mathrm{C}$. After that, it increased to about $55 \%$ at $520^{\circ} \mathrm{C}$. \%. It was seemed that this amount was high by comparing other studies. For example, Chaiwong et al. (2013) found liquid yield as $45 \%$ at $520{ }^{\circ} \mathrm{C}$ [19]. Liquid product yield stood at $55 \%$ till $620{ }^{\circ} \mathrm{C}$. At that temperature, liquid product yield decreased from $55 \%$ to $50 \%$. In brief, maximum liquid product yield was obtained between 520 and $570{ }^{\circ} \mathrm{C}$ for Spirulina's conventional pyrolysis under our specific conditions in the study. That data was compatible with other studies. For example, Chen et al. (2017), obtained maximum liquid product yield at between 500 and $600{ }^{\circ} \mathrm{C}$ for Spirulina's pyrolysis [20].

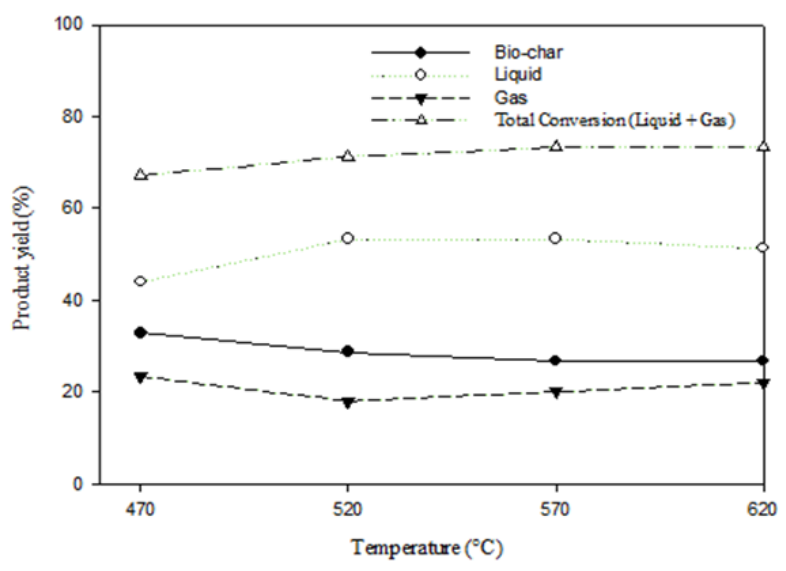

Fig. 3. Change in product yields with temperature

Effect of temperature on the bio-oil and aqueous phase yields was presented in Fig. 4. Bio-oil product yield was obtained as nearly $20 \%$ at $470^{\circ} \mathrm{C}$. After that, it increased to about $40 \%$. And it stood at that value till $620{ }^{\circ} \mathrm{C}$. At that temperature, 
liquid product yield decreased from $40 \%$ to $30 \%$. Aqueous phase yield was obtained as around $20 \%$ at all temperatures. It was obtained as $20 \%$ at $470^{\circ} \mathrm{C}$. And then, it stood nearly $15 \%$ till $620{ }^{\circ} \mathrm{C}$. At that temperature, aqueous phase yield increased from $15 \%$ to $18 \%$. In summary, maximum bio-oil and aqueous phase yield were achieved at 520 and $470{ }^{\circ} \mathrm{C}$ respectively. That finding was compatible with other studies. Pan et al. (2010), were observed maximum bio-oil and aqueous phase yield were approximately $30 \mathrm{wt} . \%$ and $20 \mathrm{wt}$. $\%$ respectively as a result of their slow pyrolysis research for Nannochloropsis sp. Microalgae [29].

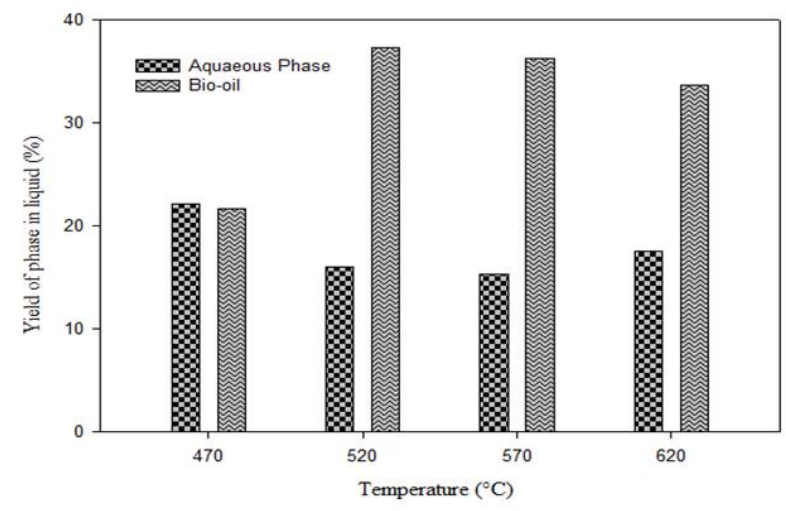

Fig. 4. Change in bio-oil and aqueous phase yield with temperature

\subsection{Chemical composition of liquid product}

Chromatogram for bio-oil were shown in Fig. 5. Structure of some components which were found in bio-oil was added to the chromatogram with respect to their retention times.
Considering that, it was deduced that bio-oil composed of aliphatic and cyclic hydrocarbons (such as toluene and heptadecane), oxygenated components (such as phenol, ocresol and nonadecanol), nitrogenous components (such as hexadecane amide and 3-Methyl-1H-indole). Retention times and peak areas of each component in bio-oil were taken place in Table 2. It was understood that oxygenated compounds (43\%) formed the main part of bio-oil. Nitrogenous compounds (26\%) and hydrocarbons (19\%) were also found in bio-oil highly. Samely, Dai et. al. (2019) found that oxygenated compounds and nitrogenous compounds were comprised of nearly $40 \%$ and $25 \%$ of bio-oil at $600{ }^{\circ} \mathrm{C}$ [30] . It was determined also other compounds (12\%) in bio-oil which composed of both nitrogen and oxygen such as piperidone and hexadecane amide. It must be noted that while it was forming that table, it was regarded only $40 \%$ of the total peak area. Because it was determined that bio-oil composed of other several components which had long name and low peak area percentage. In Fig. 6, change in peak area of some component with temperature was given. It was seemed that rise in temperature had positive effect on the amount of pyrrole and hexadecane amide while phenol and toluene amount decreased with increasing temperature.

It was detected that peak area of some compounds in bio-oil were higher than other researches. For example, Anand et al. (2016) has found that peak area percentage of pyrrole and phenol were 0.6 and 1.93 respectively at $600{ }^{\circ} \mathrm{C}$ [22]. Chaiwong et. al. (2013), has obtained bio-oil that comprised of $0.37 \%$ toluene and $1.14 \%$ phenol at $550{ }^{\circ} \mathrm{C}$ [27].

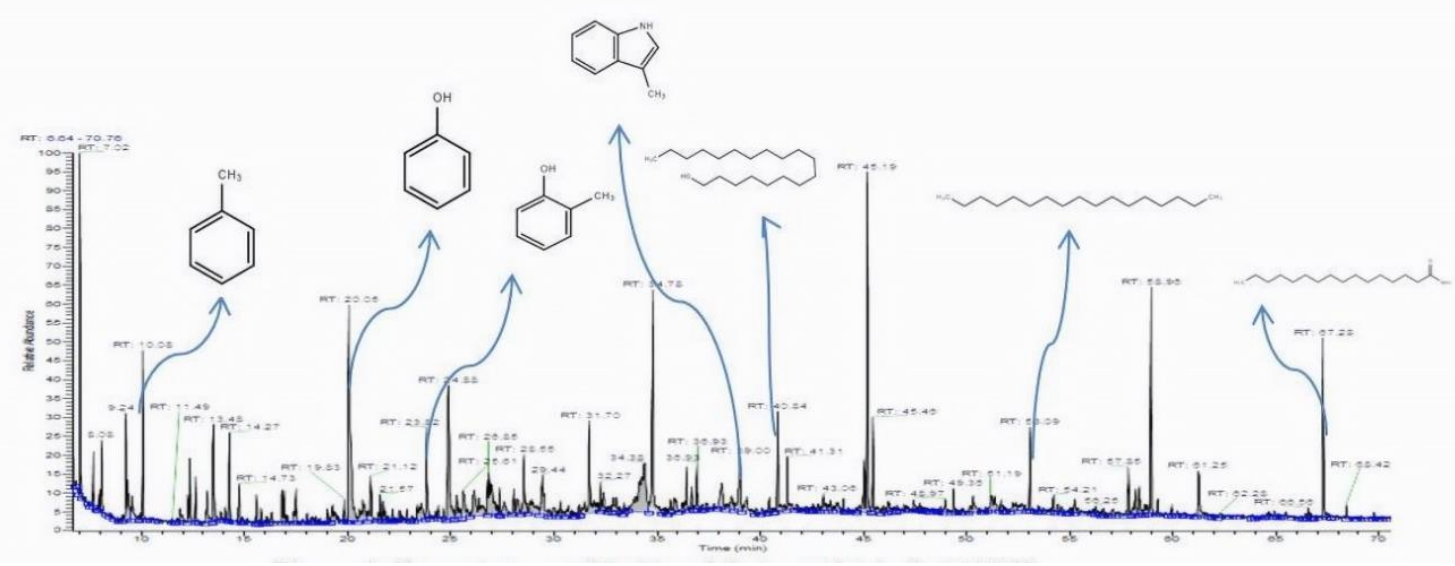

Fig. 5. Chromatogram of the bio-oil that was obtained at $520^{\circ} \mathrm{C}$

Aqueous phase components in the liquid product were determined in the same approach. Retention times and peak areas of each component in aqueous phase were taken place in Table 3. Unlike bio-oil, hydrocarbons like toluene, ethyl benzene, styrene and alkanes were not detected in aqueous phase. It was understood that oxygenated compounds (45\%) formed the main part of aqueous phase and nitrogenous compounds $(28 \%)$ followed that. At that time, amount of other compounds (27\%) which had both nitrogen and oxygen was high compared to bio-oil. These compounds occurs because of protein degradation in Spirulina [31]. These differences was shown in the aqueous phase chromatogram also (Fig. 7). To the best of our knowledge, there have been little information about aqueous phase composition of Spirulina in literature. Jena and Das (2011), obtained aqueous phase which included acetic acid and some nitrogenous compounds such as pyrazine and amids at $350{ }^{\circ} \mathrm{C}$ [31]. 
Table 2. Components in bio-oil of Spirulina that was obtained at $520{ }^{\circ} \mathrm{C}$

\begin{tabular}{|c|c|c|c|c|c|c|c|}
\hline $\begin{array}{l}\text { Retention } \\
\text { time, min }\end{array}$ & Component & Formula & $\begin{array}{c}\text { Peak } \\
\text { Area, \% }\end{array}$ & $\begin{array}{l}\text { Retention } \\
\text { time, min }\end{array}$ & Component & Formula & $\begin{array}{c}\text { Peak } \\
\text { Area, \% }\end{array}$ \\
\hline 3.92 & octanal & $\mathrm{C}_{8} \mathrm{H}_{16} \mathrm{O}$ & 1.47 & 17.49 & $\begin{array}{l}\text { 1H-pyrazole, 3,5- } \\
\text { dimethyl- }\end{array}$ & $\mathrm{C}_{5} \mathrm{H}_{8} \mathrm{~N}_{2}$ & 0.53 \\
\hline 4.14 & acetic acid, hydroxy- & $\mathrm{C}_{2} \mathrm{H}_{4} \mathrm{O}_{3}$ & 2.81 & 18.04 & 2-ethyl-furan & $\mathrm{C}_{6} \mathrm{H}_{8} \mathrm{O}$ & 0.13 \\
\hline 4.44 & acetic acid, cyano- & $\mathrm{C}_{3} \mathrm{H}_{3} \mathrm{NO}_{2}$ & 1.87 & 18.33 & 2,3-dimethyl-1H-pyrrole & $\mathrm{C}_{6} \mathrm{H}_{9} \mathrm{~N}$ & 0.12 \\
\hline 5.23 & Cyclobutanecarbonitrile & $\mathrm{C}_{5} \mathrm{H}_{7} \mathrm{~N}$ & 0.31 & 19.26 & $\begin{array}{c}\text { Octanenitrile, } 2- \\
\text { methylene- }\end{array}$ & $\mathrm{C}_{9} \mathrm{H}_{15} \mathrm{~N}$ & 0.52 \\
\hline 6.86 & benzene & $\mathrm{C}_{6} \mathrm{H}_{6}$ & 0.06 & 20.05 & phenol & $\mathrm{C}_{6} \mathrm{H}_{6} \mathrm{O}$ & 4.54 \\
\hline 7.02 & $\begin{array}{l}\text { furan tetrahydro-2- } \\
\text { methyl- }\end{array}$ & $\mathrm{C}_{5} \mathrm{H}_{10} \mathrm{O}$ & 1.98 & 20.75 & 4-aminopyridine & $\mathrm{C}_{5} \mathrm{H}_{6} \mathrm{~N}_{2}$ & 0.76 \\
\hline 8.08 & Butanenitrile, 3-methyl- & $\mathrm{C}_{5} \mathrm{H}_{9} \mathrm{~N}$ & 0.81 & 21.12 & furan, 2-ethyl, 5-methyl- & $\mathrm{C}_{7} \mathrm{H}_{10} \mathrm{O}$ & 0.85 \\
\hline 9.24 & pyrrole & $\mathrm{C}_{4} \mathrm{H}_{5} \mathrm{~N}$ & 1.7 & 21.57 & nonanol & $\mathrm{C}_{9} \mathrm{H}_{20} \mathrm{O}$ & 0.33 \\
\hline 9.56 & Pentanenitrile & $\mathrm{C}_{5} \mathrm{H}_{9} \mathrm{~N}$ & 0.51 & 22.18 & tetradecane & $\mathrm{C}_{14} \mathrm{H}_{30}$ & 0.12 \\
\hline 10.08 & toluene & $\mathrm{C}_{7} \mathrm{H}_{8}$ & 1.45 & 22.52 & benzene, 1-propenyl- & $\mathrm{C}_{9} \mathrm{H}_{10}$ & 0.24 \\
\hline 10.55 & 2-Methylpentane & $\mathrm{C}_{6} \mathrm{H}_{14}$ & 0.06 & 22.88 & 3-pyridinemethanol & $\mathrm{C}_{6} \mathrm{H}_{7} \mathrm{NO}$ & 0.17 \\
\hline 11.73 & 3-Methylpyridine & $\mathrm{C}_{6} \mathrm{H}_{7} \mathrm{~N}$ & 0.05 & 23.82 & o-cresol & $\mathrm{C}_{7} \mathrm{H}_{8} \mathrm{O}$ & 1.12 \\
\hline 11.87 & octane & $\mathrm{C}_{8} \mathrm{H}_{18}$ & 0.33 & 24.88 & m-cresol & $\mathrm{C}_{7} \mathrm{H}_{8} \mathrm{O}$ & 2.78 \\
\hline 12.34 & Pentanenitrile, 4-methyl- & $\mathrm{C}_{6} \mathrm{H}_{11} \mathrm{~N}$ & 0.73 & 40.43 & nonadecane & $\mathrm{C}_{19} \mathrm{H}_{40}$ & 2.78 \\
\hline 12.62 & 2-methyl-1H-pyrrole & $\mathrm{C}_{5} \mathrm{H}_{7} \mathrm{~N}$ & 0.44 & 40.84 & nonadecanol & $\mathrm{C}_{19} \mathrm{H}_{40} \mathrm{O}$ & 1.24 \\
\hline 13.19 & Pyrazine & $\mathrm{C}_{4} \mathrm{H}_{4} \mathrm{~N}_{2}$ & 0.59 & 49.36 & hexadecane & $\mathrm{C}_{16} \mathrm{H}_{34}$ & 0.29 \\
\hline 13.48 & 2-piperidone & $\mathrm{C}_{5} \mathrm{H}_{9} \mathrm{NO}$ & 1.09 & 53.09 & heptadecane & $\mathrm{C}_{17} \mathrm{H}_{36}$ & 0.82 \\
\hline 14.07 & Hexanenitrile & $\mathrm{C}_{6} \mathrm{H}_{11} \mathrm{~N}$ & 0.14 & 54.21 & dodecane & $\mathrm{C}_{12} \mathrm{H}_{26}$ & 0.22 \\
\hline 14.27 & N-Methylaniline & $\mathrm{C}_{7} \mathrm{H}_{9} \mathrm{~N}$ & 0.73 & 57.85 & oleic acid & $\mathrm{C}_{18} \mathrm{H}_{34} \mathrm{O}_{2}$ & 0.63 \\
\hline 14.73 & o-xylene & $\mathrm{C}_{8} \mathrm{H}_{10}$ & 0.46 & 58.17 & cyclododecane & $\mathrm{C}_{12} \mathrm{H}_{24}$ & 0.56 \\
\hline 15.09 & 2,5-dimethylpyridine & $\mathrm{C}_{7} \mathrm{H}_{9} \mathrm{~N}$ & 0.08 & 58.96 & hexadecane nitrile & $\mathrm{C}_{16} \mathrm{H}_{31} \mathrm{~N}$ & 2.24 \\
\hline 15.56 & styrene & $\mathrm{C}_{8} \mathrm{H}_{8}$ & 0.28 & 59.26 & $\begin{array}{c}\text { cyclopentadecanone, } 2- \\
\text { hydroxy- }\end{array}$ & $\mathrm{C}_{15} \mathrm{H}_{28} \mathrm{O}_{2}$ & 0.16 \\
\hline 15.81 & ethylbenzene & $\mathrm{C}_{8} \mathrm{H}_{10}$ & 0.18 & 61.25 & N-hexadecanoic acid & $\mathrm{C}_{16} \mathrm{H}_{32} \mathrm{O}_{2}$ & 0.79 \\
\hline 16.81 & 2-methyl-1H-pyrrole & $\mathrm{C}_{5} \mathrm{H}_{7} \mathrm{~N}$ & 0.66 & 67.28 & hexadecane amide & $\mathrm{C}_{16} \mathrm{H}_{33} \mathrm{NO}$ & 1.93 \\
\hline
\end{tabular}



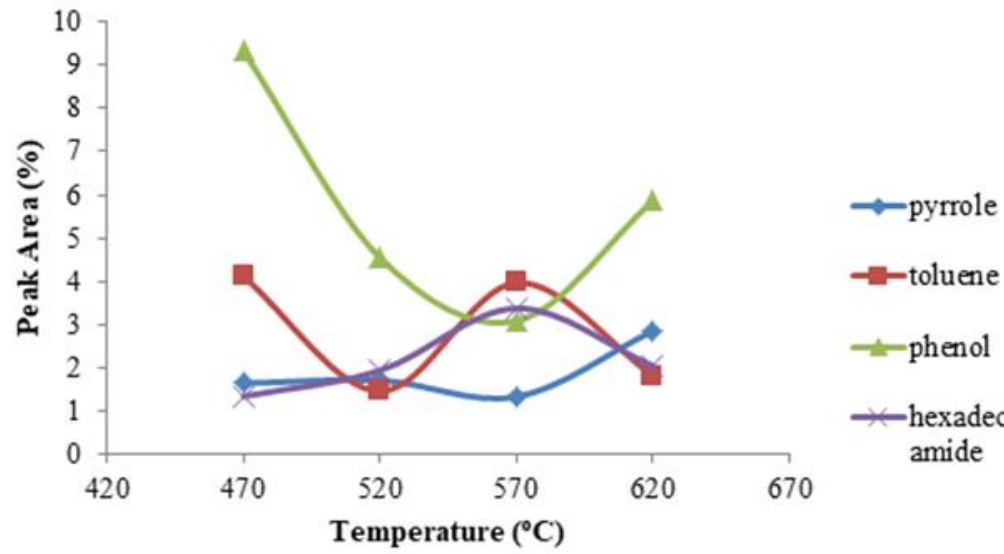

- phenol

-hexadecane amide

Fig. 6. Component distribution of bio-oil with temperature

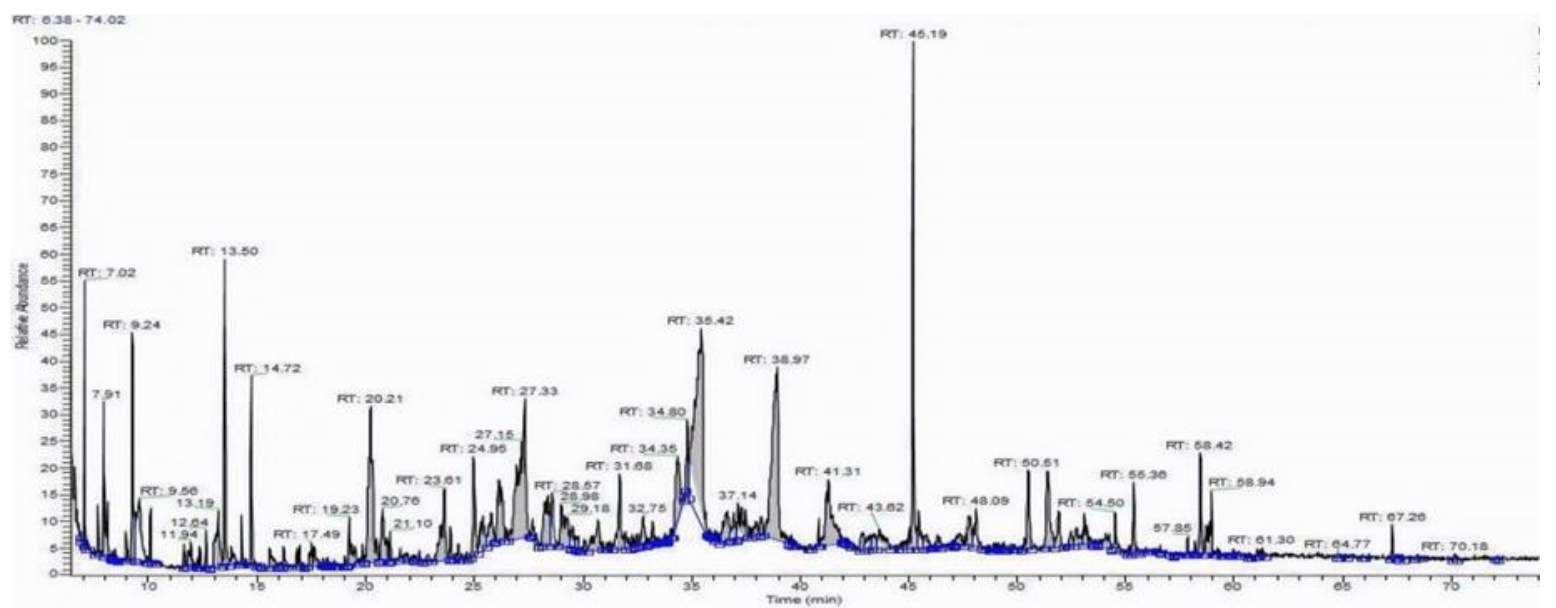

Fig. 7. Chromatogram of the aqueous phase that was obtained at $520^{\circ} \mathrm{C}$

Table 3. Components in aqueous phase of Spirulina that was obtained at $520{ }^{\circ} \mathrm{C}$

\begin{tabular}{cccc}
\hline Retention time, min & Component & Formula & Peak area, \% \\
\hline 4.14 & acetic acid, hydroxy- & $\mathrm{C}_{2} \mathrm{H}_{4} \mathrm{O}_{3}$ & 7.48 \\
4.44 & acetic acid, cyano- & $\mathrm{C}_{3} \mathrm{H}_{3} \mathrm{NO}_{2}$ & 5.9 \\
5.23 & Cyclobutanecarbonitrile & $\mathrm{C}_{5} \mathrm{H}_{7} \mathrm{~N}$ & 0.78 \\
7.02 & furan tetrahydro-2-methyl- & $\mathrm{C}_{5} \mathrm{H}_{10} \mathrm{O}$ & 0.91 \\
9.24 & pyrrole & $\mathrm{C}_{4} \mathrm{H}_{5} \mathrm{~N}$ & 1.75 \\
9.56 & Pentanenitrile & $\mathrm{C}_{5} \mathrm{H}_{9} \mathrm{~N}$ & 1.38 \\
12.25 & Pentanenitrile, 4-methyl- & $\mathrm{C}_{6} \mathrm{H}_{11} \mathrm{~N}$ & 0.05 \\
12.64 & 2-methyl-1H-pyrrole & $\mathrm{C}_{5} \mathrm{H}_{7} \mathrm{~N}$ & 0.2 \\
13.19 & Pyrazine & $\mathrm{C}_{4} \mathrm{H}_{4} \mathrm{~N}_{2}$ & 1.12 \\
13.5 & 2-piperidone & $\mathrm{C}_{5} \mathrm{H}_{9} \mathrm{NO}_{1}$ & 1.97 \\
13.78 & Hexanenitrile & $\mathrm{C}_{6} \mathrm{H}_{11} \mathrm{~N}$ & 0.28 \\
17.49 & $\mathrm{C}_{5} \mathrm{H}_{8} \mathrm{~N}_{2}$ & 0.54 \\
18.03 & 2-ethyl-furan & $\mathrm{C}_{6} \mathrm{H}_{8} \mathrm{O}$ & 0.05 \\
18.22 & $\mathrm{C}_{6} \mathrm{H}_{9} \mathrm{~N}$ & 0.05 \\
19.23 & 1H-pyrazole, 3,-dimethyl- & $\mathrm{C}_{9} \mathrm{H}_{15} \mathrm{~N}$ & 0.66 \\
20.21 & 2,3-dimethyl-1H-pyrrole & $\mathrm{C}_{6} \mathrm{H}_{6} \mathrm{O}$ & 3.25 \\
20.76 & Octanenitrile, 2-methylene- & $\mathrm{C}_{5} \mathrm{H}_{6} \mathrm{~N}_{2}$ & 0.92 \\
21.1 & phenol & $\mathrm{C}_{7} \mathrm{H}_{10} \mathrm{O}$ & 0.19 \\
21.57 & 4-aminopyridine & $\mathrm{C}_{9} \mathrm{H}_{20} \mathrm{O}$ & 0.06 \\
22.89 & furan, 2-ethyl, 5-methyl- & $\mathrm{C}_{6} \mathrm{H}_{7} \mathrm{NO}^{2}$ & 0.1 \\
23.61 & nonanol & $\mathrm{C}_{7} \mathrm{H}_{8} \mathrm{O}$ & 1.5 \\
40.86 & 3-pyridinemethanol & $\mathrm{C}_{19} \mathrm{H}_{40} \mathrm{O}$ & 0.15 \\
57.85 & o-cresol & $\mathrm{C}_{18} \mathrm{H}_{34} \mathrm{O}_{2}$ & 0.12 \\
58.94 & nonadecanol & $\mathrm{C}_{16} \mathrm{H}_{31} \mathrm{~N}$ & 0.88 \\
59.24 & oleic acid & $\mathrm{C}_{15} \mathrm{H}_{28} \mathrm{O}_{2}$ & 0.09 \\
67.26 & $\mathrm{C}_{16} \mathrm{H}_{33} \mathrm{NO}_{2}$ & 0.25 \\
\hline
\end{tabular}




\section{Conclusions}

Pyrolysis of Spirulina sp. microalgae was carried out. First of all, elemental analysis of Spirulina showed that the microalgae had high carbon and oxygen content. For thermal pyrolysis of Spirulina, maximum liquid product was obtained at 520 and $570{ }^{\circ} \mathrm{C}$ as $55 \%$. By comparing other studies, this amount was found high. It was detected that bio-oil of Spirulina composed of hydrocarbons, oxygenated and nitrogenous compounds. Specifically, hydrocarbons were found in the form of alkanes and aromatic compounds like benzene, styrene, toluene and ethyl benzene. It was detected that peak area of some compounds like phenol, pyrrole and toluene in bio-oil were higher than other researches. Unlike bio-oil, hydrocarbons like toluene, ethyl benzene, styrene and alkanes were not detected in aqueous phase. But reached percentage of oxygenated and nitrogenous compounds in the aqueous phase was nearly same as bio-oil. This reserarch was showed that liquid phase of microalgae especially bio-oil can be used as carbon-neutral fuel after advanced upgrading techniques.

\section{Acknowledgment}

We would like to thank Ankara University Coordinatorship of Scientific Research Projects for financial support (Project Number: 17L0443014).

\section{ORCID}

Gamze Özçakır

Ali Karaduman

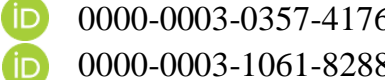

\section{References}

[1] Kothari R., Tyagi V. V., Pathak A. 2010. Waste-toenergy: A way from renewable energy sources to sustainable development. Renewable and Sustainable Energy Reviews, 14, 3164-70.

[2] Wu X., Wu Y., Wu K., Chen Y., Hu H., Yang M. 2015. Study on pyrolytic kinetics and behavior: The copyrolysis of microalgae and polypropylene. Bioresource Technology, 192, 522-8.

[3] Kan T., Strezov V., Evans T. J. 2016. Lignocellulosic biomass pyrolysis: A review of product properties and effects of pyrolysis parameters. Renewable and Sustainable Energy Reviews, 57, 1126-40. https://doi.org/10.1016/j.rser.2015.12.185.

[4] Jin H., Hanif M.U., Capareda S., Chang Z., Huang H., Ai Y. 2016. Copper(II) removal potential from aqueous solution by pyrolysis biochar derived from anaerobically digested algae-dairy-manure and effect of $\mathrm{KOH}$ activation. Journal of Environmental Chemical Engineering, 4, 365-72.
[5] Demirbas A. 2008. Biofuels sources, biofuel policy, biofuel economy and global biofuel projections. Energy Conversion and Management, 49, 2106-16.

[6] Rodionova M. V., Poudyal R. S., Tiwari I., Voloshin R. A., Zharmukhamedov S. K., Nam H. G. 2017. Biofuel production: Challenges and opportunities. International Journal of Hydrogen Energy, 42, 8450-61.

[7] Chen W., Li K., Xia M., Yang H., Chen Y., Chen X. 2018. Catalytic deoxygenation co-pyrolysis of bamboo wastes and microalgae with biochar catalyst. Energy, 157, 472-82.

[8] Gómez Millán G., Hellsten S., Llorca J., Luque R., Sixta H., Balu A. M. 2019. Recent Advances in the Catalytic Production of Platform Chemicals from Holocellulosic Biomass. ChemCatChem, 11, 2022-42.

[9] Tian M., Zhu Y., Zhang D., Wang M., Chen Y., Yang Y. 2019. Pyrrolic-nitrogen-rich biomass-derived catalyst for sustainable degradation of organic pollutant via a self-powered electro-Fenton process. Nano Energy, 64, 103940.

[10] Hossain S. M. Z. 2019. Biochemical Conversion of Microalgae Biomass into Biofuel. Chemical Engineering Technology, 42, 2594-607.

[11] Marcon N. S., Colet R., Bibilio D., Graboski A. M., Steffens C., Rosa C. D. 2019. Production of Ethyl Esters by Direct Transesterification of Microalga Biomass Using Propane as Pressurized Fluid. Applied Biochemistry and Biotechnology, 187, 1285-99.

[12] Panwar N. L., Kothari R., Tyagi V. V. 2012. Thermo chemical conversion of biomass - Eco friendly energy routes. Renewable and Sustainable Energy Reviews, 16 , 1801-16.

[13] Luque R., Menéndez J. A., Arenillas A., Cot J. 2012 Microwave-assisted pyrolysis of biomass feedstocks: The way forward?. Energy \& Environmental Science, $5,5481-8$.

[14] Abhijeet P., Swagathnath G., Rangabhashiyam S., Asok Rajkumar M., Balasubramanian P. 2020. Prediction of pyrolytic product composition and yield for various grass biomass feedstocks. Biomass Conversion and Biorefinery, 10, 663-74.

[15] Akhtar J., Saidina Amin N. 2012. A review on operating parameters for optimum liquid oil yield in biomass pyrolysis. Renewable and Sustainable Energy Reviews, 16, 5101-9.

[16] Moreira D., Pires J. C. M. 2016. Atmospheric CO2 capture by algae: Negative carbon dioxide emission path. Bioresource Technology, 215, 371-9.

[17] Li Y., Horsman M., Wu N., Lan C. Q., Dubois-Calero N. 2008. Biofuels from Microalgae. Biotechnology Progress, 24, 815-20.

[18] Huang Y., Chen Y., Xie J., Liu H., Yin X., Wu C. 2016. Bio-oil production from hydrothermal liquefaction of 
high-protein high-ash microalgae including wild Cyanobacteria sp. and cultivated Bacillariophyta sp.. Fuel, 183, 9-19.

[19] Chaiwong K., Kiatsiriroat T., Vorayos N., Thararax C. 2013. Study of bio-oil and bio-char production from algae by slow pyrolysis. Biomass and Bioenergy, 56, $600-6$.

[20] Chen W., Yang H., Chen Y., Xia M., Yang Z., Wang X. 2017. Algae pyrolytic poly-generation: Influence of component difference and temperature on products characteristics. Energy, 131, 1-12.

[21] Andrade L. A, Batista F. R. X., Lira T. S., Barrozo M. A. S., Vieira L. G. M. 2017. Characterization and product formation during the catalytic and non-catalytic pyrolysis of the green microalgae Chlamydomonas reinhardtii. Renewable Energy, 119, 731-40.

[22] Anand V., Sunjeev V., Vinu R. 2016. Catalytic fast pyrolysis of Arthrospira platensis (spirulina) algae using zeolites. Journal of Analytical and Applied Pyrolysis, 118, 298-307.

[23] Costa J. A. V., Freitas B. C. B., Rosa G. M., Moraes L., Morais M. G., Mitchell B. G. 2019. Operational and economic aspects of Spirulina-based biorefinery. Bioresource Technology, 292, 121946.

[24] Li J., Qiao Y., Zong P., Wang C., Tian Y., Qin S. 2019. Thermogravimetric Analysis and Isoconversional Kinetic Study of Biomass Pyrolysis Derived from Land, Coastal Zone, and Marine. Energy \& Fuels, 33, 3299310.

[25] Chagas B. M. E., Dorado C., Serapiglia M. J., Mullen C. A., Boateng A. A., Melo M. A. F. 2016. Catalytic pyrolysis-GC/MS of Spirulina: Evaluation of a highly proteinaceous biomass source for production of fuels and chemicals. Fuel, 179, 124-34.

[26] Vasudev V., Ku X., Lin J. 2020. Pyrolysis of algal biomass: Determination of the kinetic triplet and thermodynamic analysis. Bioresource Technology, 317 , 124007.

[27] Chaiwong K., Kiatsiriroat T., Vorayos N., Thararax C. 2013. Study of bio-oil and bio-char production from algae by slow pyrolysis. Biomass and Bioenergy, 56, 600-6.

[28] Yuan T., Tahmasebi A., Yu J. 2015. Comparative study on pyrolysis of lignocellulosic and algal biomass using a thermogravimetric and a fixed-bed reactor. Bioresource Technology, 175, 333-41.

[29] Pan P., Hu C., Yang W., Li Y., Dong L., Zhu L. 2010. The direct pyrolysis and catalytic pyrolysis of Nannochloropsis sp. residue for renewable bio-oils. Bioresource Technology, 101, 4593-9.

[30] Dai M., Yu Z., Fang S., Ma X. 2019. Behaviors, product characteristics and kinetics of catalytic co-pyrolysis spirulina and oil shale. Energy Conversion and Management, 192, 1-10.

[31] Jena U., Das K. C. 2011. Comparative Evaluation of Thermochemical Liquefaction and Pyrolysis for BioOil Production from Microalgae. Energy \& Fuels, 25, $5472-82$. 